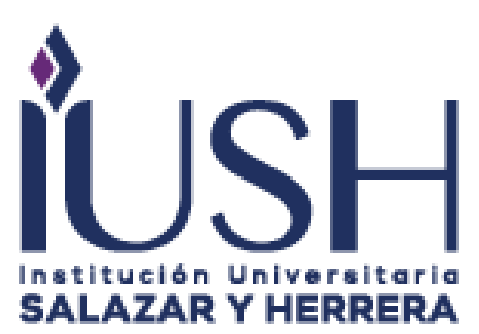

QUID 2017, pp. 1438-1443, Special Issue N¹- ISSN: 1692-343X, Medellín-Colombia

\title{
SOME PROCEDURAL STATUS PROBLEMS OF ACCUSED JUVENILE BY THE CODE OF CRIMINAL PROCEDURE OF THE RUSSIAN FEDERATION
}

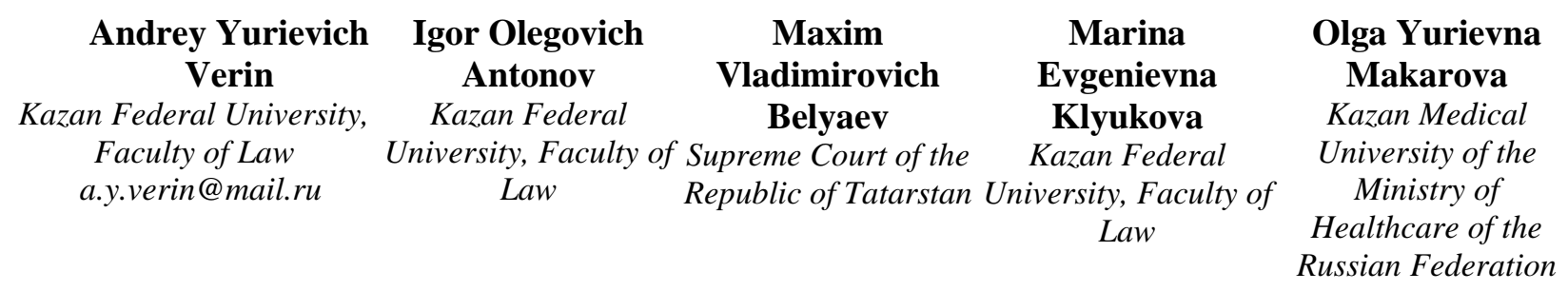

\begin{abstract}
The regulation of procedural status of the minor defendant remains urgent due to incomplete and consecutive standard regulation and, as a result, its theoretical cover. It is essential to improve the criminal procedure legislation concerning minor participants of criminal legal proceedings within raising negative tendencies of minor's crime in the Russian Federation.

The legislator, unfortunately, did not manage to avoid a so-called double context in understanding of category "minor" in a number of articles of the Code of Criminal Procedure of the Russian Federation. In this regard it is possible to say that present norms of the Code of Criminal Procedure of the Russian Federation which regulate the procedural status of the minor defendant need more detailed structure and updated contents. It will set a legal basis for more effective law enforcement and finally, judicial authorities will respond to modern challenges more adequately, i.e. state and tendencies of development of minor's crime in the Russian Federation, and also will provide more procedural guarantees of the rights and legitimate interests of the minor defendants required by the international regulations.

The present complex of procedural means of the Russian Federation can be used to protect the rights and legitimate interests of minor participants of criminal legal proceedings. Certainly, it needs to be reconsidered and updated according to urgent present requirements and challenges.
\end{abstract}

Keywords: minor, the procedural status, criminal legal proceedings, the minor suspect, the minor accused, the minor defendant, the complicated procedure, the simplified procedure.

Citar, estilo APA: Verin, A., Antonov, I., Belyaev, M., Klyukova, M. \& Makarova, O. (2017). Some procedural status problems of accused juvenile by the code of criminal procedure of the Russian federation. Revista QUID (Special Issue), 1438-1443. 


\section{INTRODUCTION}

In given criminal circumstances, the society and the state search for optimum ways to increase efficiency of criminal legal proceedings by improving the norms regulating the procedural status of the minor defendant, in particular.

In total the Russian Federation courts of law in 2014 condemned 24379 minors, in 2015 - 23156 minors, in 2016 - 24420 minors (Judicial statistics of Judicial department at the Supreme Court of the Russian Federation, n. d).

Criminal acts of minors tend to grow. So, the analysis of crime in the Republic of Tatarstan in 12 months 2015 showed 15,6\% increase of the crimes committed by minors (from 1127 to 1303), its specific weight was $4,9 \%$ (YOY - 4,9\%) and primarily, the focus was on serious and the most serious crimes (Statistical Prosecutor's offices of RT, 2015). According to the Supreme Court of the Republic of Tatarstan in 201415373 minors, in 2015 - 16278 minors, in 2016 - 15074 minors were condemned. The number comprises the following statistics on collective crime: 207 people in 2014 , in 2015 - 243 persons, in 2016 - 258.

The analysis of statistics on quantitative characteristic of minor's crime predetermines application to standards of chapter 50 of the Code of Criminal Procedure of the Russian Federation which define specifics of production on criminal cases with participation of minor defendants.

The background analysis of application of a complex of the rights and duties of the minor defendant forms its contradictory assessment. On the one hand, obviously, they are to be applied at pre-judicial and judicial stages of criminal legal proceedings in the cases provided by the law. On the other hand, it should be noted that some positions of the minor in the procedural status remain inaccurate and inconsistent. Thus, the purposes to protect the rights and freedoms of the minor defendant provided by the legislator may fail to be implemented in full. Namely, the purpose to provide minors with the most acceptable number of guarantees of their rights and legitimate interests because minors are the most vulnerable subjects of legal relationship concerning implementation of their criminal prosecution.
The abovementioned causes need to improve legal regulation of the procedural status of the minor defendant and its realization, with reference to positive foreign background in the field.

\section{MATERIALS AND METHODS}

Primarily, the methodological basis of our research rests on a fundamental dialectic method of knowledge of the social and legal phenomena under study, methods of the analysis, questioning, and also a comparative and legal method. The statistical method was applied to reveal dynamics and prevalence of application of the institute under study.

The comparative and legal method is significant to study the legal phenomena. In particular, our research on the procedural status of the minor defendant demonstrates a basic need to analyse foreign experience in legal regulation and to apply the best of it to the Russian Federation. It predetermined our interest in a wide range of foreign researches in sphere under study. Among them works of such scientists, as: (Nunez, N. et.al, 2007), (Fondacaro, 2014), (Fitz-Gibbon, 2016), (Mlyniec, 2010), (Peterson-Badali \& Warling, 2003), (Thi Thanh Nga Pham, 2015), (Kumar \& Sathish, 2014), (Rastogi \& Yadav, 2013), (Tyagi, 2016),

Our researches rested on the method of the analysis of judicial, investigative, public prosecutor's and supervising practice concerning minor participants of criminal legal proceedings (i.e. statistical data of Judicial department at the Supreme Court of the Russian Federation, the Supreme Court of RT and Prosecutor's office of RT (2014-2016).

\section{RESEARCH RESULTS}

A. Unfortunately, the Code of Criminal Procedure of the Russian Federation does not define "minor defendant" in full. At the same time, the term "minor" used in various contexts, certainly, cannot but complicate law-enforcement practice.

The status of the minor defendant is defined as a possibility of the person to bear criminal liability for committed criminal act, primarily, at definite age. It causes the lower age limit set by the criminal legislation namely - 14 or 16 years. The upper age limit is 18 years. However the existing Code of Criminal Procedure of the Russian 
Federation is not always consecutive in understanding of the minor and, the minor defendant, in particular.

B. According to standards of chapter 50 of the Code of Criminal Procedure of the Russian Federation which regulate the main features of production on criminal cases concerning minors and are applied to criminal cases to the people underage by the time of crime commission (p.1 by Art. 420 of the Code of Criminal Procedure of the Russian Federation). Thus, the legislator considers a minority of the criminally prosecuted person at the time of commission of crime and actually tells nothing about his age during criminal case production. There is a reasonable question of correlation of the term 'minor' and the contents and purpose of the norms of this chapter, and whether it corresponds to the notions of "minor suspect" or "minor accused" or "minor defendant" which are often used in legal literature considering procedural features of production on affairs of minors.

Frequently, the person underage at the time of commission of crime becomes full age by the time of criminal case production or in the course of its implementation. At the same time, the legislator ignored this situation when defining features of production on criminal cases concerning minors.

In this regard it is reasonable to introduce the point stating the terms "minor suspect", "the minor accused", and "the minor defendant" as the persons who received the corresponding procedural status according to norms of the Criminal Procedure Code of the Russian Federation (the Art. of Art. 46. 47), and persons underage by the time of criminal case production (production of procedural action or adoption of the proceeding decision) into Art. 5 of the Code of Criminal Procedure of the Russian Federation

C. In some cases the Russian legislator did not manage to avoid a double context in interpretation of the status of the minor. For example, in Art. 422 of the Code of Criminal Procedure of the Russian Federation, which establishes the rule of allocation of criminal case concerning the minor into separate production. On the one hand, the specified norm focuses on the minor participating in commission of crime along with the adult, on the other hand, the minor joined to criminal case with the adult to who as the legislator specifies, rules of Art. 50 of the Code of Criminal Procedure of the Russian Federation are applied and, thus allocation of criminal case in separate production is impossible. This edition of Art. 422 of the Code of Criminal Procedure of the Russian Federation leaves an important question unanswered - whether it is necessary to allocate criminal case concerning the person of full legal age at the time of majority decision-making in separate production? It is considered that in this case the answer has to be negative since proceeding from literal interpretation of the specified norm, it is possible to draw a conclusion that the procedural guarantees provided by this chapter concerning minors are not applied to the persons at full age.

D. Traditionally it was considered that even in case of person being at full age at the time of production of procedural actions or adoption of proceeding decisions within criminal legal proceedings, all additional procedural guarantees of the rights of minor defendants provided by the legislation are also applied to them. In many respects such position was determined by the explanations given in earlier existing Resolution of the Plenum of the Supreme Court of the Russian Federation of 14.02.2000 No. 7 "On legal practice in cases of crimes of minors" (2000), which state that "by hearing of cases about crimes of minors... participation of the defender (lawyer) on such affairs is obligatory... irrespective of whether the defendant is at full age by this time".

Absolutely different approach to solve this problem is stated at the Plenum of the Supreme Court of the Russian Federation of the current resolution on the similar question 'On legal practice of Application of the Legislation Regulating Features of Criminal Liability and Punishment of Minors'. So, item 8 of this resolution states that "minors can exercise the right for protection by themselves, as well as by the defender, the legal representative (part 1 of article 16, articles 48 and 428 Codes of Criminal Procedure of the Russian Federation). The invitation, appointment and replacement of the defender is carried out in the procedure provided by article 50 Code of Criminal Procedure of the Russian Federation considering other norms which establish additional guarantees to exercise the right for protection of minors which are not valid as soon as person is at full age. According to item 12 of this resolution, if the person is underage during crime commitment and at full age during consideration of the case in court, generally actions by the legal representative cease (2011).

In other words, all juvenile technologies provided by the law should not be applied to such persons. 
Such position is quite logical and reasonable since ensuring the rights of the minor with additional procedural guarantees is determined by age of the person who committed a crime and, as a result of it, by the level of his mental development, limited capacity, financial position.

E. Another essentially important point at disclosure of the procedural status of the minor defendant in the criminal legislation is to allocate a group of persons who legally, according to the status, are equated to the minors who committed a crime. According to Art. 96 of the Criminal Code of the Russian Federation in exceptional instances considering the personality and the nature of committed act the court can apply provisions of Ch. 14, focused on criminal liability and punishment of minors, regarding the persons aged from 18 up to 20 years who committed a crime, but not place them in special teaching and educational facility of the closed type or educational colony. By some estimates in the Russian Federation, the number of persons, whose physiological age does not correspond to psychological one, can be very considerable (Mashinskaya, 2013).

In this regard there is a question - to what extent the rules of chapter 50 of the Code of Criminal Procedure of the Russian Federation should be applied to these persons?

The Supreme Court of the Russian Federation did not clear up the matter. The abovementioned resolution "On legal practice of Application of the Legislation Regulating Features of Criminal Liability and Punishment of Minors" explains that the norms establishing additional guarantees to exercise the right for protection concerning minors also apply to the exceptional cases provided by Art. 96 of the Criminal Code of the Russian Federation i.e. to the persons who committed a crime aged from 18 up to 20 years (see item 8). The similar exception was made by the Supreme Court of the Russian Federation and stated participation of legal representatives, having specified that in exceptional cases realization of these functions can be continued by court adopted decision to distribute regulations on features of criminal liability of minors on persons aged from 18 years up to 20 years of (see item 12 of the specified resolution). At the same time other additional procedural guarantees intended to ensure the rights of minors are not explained in a similar way. The paragraph 15 of the resolution under study of the Supreme Court of the Russian Federation distributes the rule not to adopt a special order in the judgment concerning the minor defendant, to all persons at full age by the time of judicial proceedings.

Thus, under certain conditions the standards of chapter 50 of the Code of Criminal Procedure of the Russian Federation have to extend in exceptional cases considering the nature of committed act and the personality also to the persons who committed a crime aged from 18 up to 20 years. Besides, after introduction of amendments to the Code of Criminal Procedure of the Russian Federation the Federal law of March 4, 2013 No. 23-FL the so-called persons participating in production of procedural actions at verification of the report of a crime are mentioned at a stage of initiation of legal proceedings (the p. 1.1 of Art. 144 of the Code of Criminal Procedure of the Russian Federation). It is necessary to distinguish the person concerning whom an inspection of the report of a crime is carried out among them (Klyukova, 2015). Unlike other participants of preinvestigation verification this person is given the right to have the defender from the beginning of implementation of the procedural actions affecting his rights and freedoms (item 6 of the p. 3 of Art. 49 of the Code of Criminal Procedure of the Russian Federation). A number of authors are positive about this rule. In their opinion, it will have a positive impact on ensuring the right for protection in criminal cases primarily for the minor, and allow to come into necessary contact with the teenager at early stages of procedural activity, and also let the qualified lawyer to control procedural activity of the detective, investigator, and body of inquiry (Ignatov, 2003) (Kovalevskaya, 1970) (Mashinskaya, 2014). At the same time there is a question whether it is possible to extend the procedural guarantees provided by the law concerning minors according to Ch. 50 of Code of Criminal Procedure of the Russian Federation, in particular, regulations on participation of lawful representatives, teacher, psychologist, etc. to the minor concerning whom an inspection of the report of a crime is carried out? It believed that, as soon as the legislator establishes special procedural rules of production of cases against minors and takes into account age, physiological, social and psychological, mental and other properties of the underage persons, the rules have to be fully applicable also to minors concerning whom an inspection of the report of a crime is carried out, despite the fact they have no official status of the suspect or the defendant.

\section{SUMMARY}


A. The norms regulating guarantees of realization of legal status of the minor are presented mainly in Ch. 50 of Code of Criminal Procedure of the Russian Federation. Today the given chapter of the Code of Criminal Procedure of the Russian Federation needs more accurate structuring and contents, relevant requirements and calls of the present, a condition of minor's crime in the Russian Federation to a large extent, and also to standards of the international regulations in the sphere of protection of the rights and freedoms of participants of criminal legal proceedings.

B. Nowadays, generally speaking, Russian legal science interprets procedural status of the minor with respect to maintenance and purpose of the norms stated in chapter 50 of the Code of Criminal Procedure of the Russian Federation. At the same time, when defining features of production on criminal cases concerning minors the legislator did not pay enough attention to person who was underage at the time of commission of crime, but was at full age by the time of the beginning of production on criminal case or in the course of preliminary investigation or judicial proceedings. In this regard it is reasonable to introduce notion of the minor suspect, defendant as the person who received the corresponding procedural status according to norms of the Criminal Procedure Code of the Russian Federation (the Art. of Art. 46. 47), and who was underage by the time of criminal case production (production of procedural action or adoption of the proceeding decision) into Art. 5 of the Code of Criminal Procedure of the Russian Federation.

C. The legislator did not manage to avoid a socalled double context in understanding of category "minor" in a number of articles of Code of Criminal Procedure of the Russian Federation. In particular, on the one hand, the Art. 422 of the Code of Criminal Procedure of the Russian Federation states that the minor participates in commission of crime along with the adult, on the other hand, the minor is joined to criminal case with the adult to whom as the legislator specifies, rules of Art. 50 of the Code of Criminal Procedure of the Russian Federation are applied.

D. All legal juvenile technologies which need to be completed more accurately should not be applied to the persons at full age at the time of production on criminal case and it is consistently reflected in the Code of Criminal Procedure of the Russian Federation.
E. The legislator needs regard an adult participant of criminal trial considered as a minor. It is necessary to specify to what extent the rule of chapter 50 of the Code of Criminal Procedure of the Russian Federation has to be applicable in exceptional cases considering the nature of committed act and the personality of the persons who committed a crime aged from 18 up to 20 years on whom regulations on features of criminal liability of minors (Art. 96 of the Criminal Code of the Russian Federation) were distributed.

\section{CONCLUSION}

The norms regulating guarantees of realization of legal status of the minor defendant need more accurate structuring and updated contents to meet present requirements and challenges. In Russian legal science the understanding of the procedural status of the minor generally corresponds to the contents and purpose of standards of the criminal procedure legislation.

Changes in the legislation of criminal procedure in the Russian Federation need to apply juvenile technologies to person at full age in the course of criminal case production, when considering an adult participant of criminal trial as a minor in criminal trial, etc. In the Russian legislation it is necessary to eliminate a number of the existing gaps which do not allow full application of the existing complex of measures developed by the international community to prevent teenage crime.

ACKNOWLEDGEMENTS: The work is performed according to the Russian Government Program of Competitive Growth of Kazan Federal University.

\section{REFERENCES}

Fitz-Gibbon, K. (2016). Protections for children before the law: An empirical analysis of the age of criminal responsibility, the abolition of doli incapax and the merits of a developmental immaturity defence in England and Wales. Criminology \& Criminal Justice. 16(4), p. 391-409.

Fondacaro, M.R. (2014). Rethinking the scientific and legal implications of developmental differences research in juvenile justice. New Criminal Law Review. 17(3). p. 407-441.

Ignatov, S.D. (2003). Features of procedural activity of the lawyer defender in the matter of 
the minor defendant in court of the first instance. Lawyer practice. 4, p. 27-31

Judicial statistics of Judicial department at the Supreme Court of the Russian Federation. Retrieved 10 May 2017 from: http://www.cdep.ru/index.php?id=79

Klyukova M.E. (2015). Participants of investigation verification. Materials XII of the International scientific and practical conference "Tatishchevsky readings: urgent problems of science and practice" in 4 volumes. Volume $2 / /$ Urgent problems of jurisprudence. In 2 parts. Part I. - Tolyatti: Volga university of V.N. Tatishchev, p. 54-60.

Kovalevskaya, L.P. (1970). Protection for minors. Studying and the prevention of violations among minors. The collection of articles. under the editorship of D.S. Karev. M.: Mosk publishing house. Univ., p. 88-96;

Kumar M.V., Sathish, K.V. (2014). Age and crime. Journal of South India Medicolegal Association. 6(2), p. 69-72.

Mashinskaya, N.V. (2013). A concept of the minor of criminal trial and a problem of differentiation of a procedural form for minors. the Messenger of institute: crime, punishment, correction, No. 1, Page 34-37.

Mashinskaya, N.V. (2014). Problems of realization of the right of the minor suspect accused on protection of a stage of preliminary investigation. Messenger of the Omsk university. Series "Right". 4(41), p. 206-209.

Mlyniec, W.J. (2010). The implications of Articles 37 and 40 of the Convention on the Rights of the Child for U.S. juvenile justice and U.S. ratification of the Convention. Child Welfare. 89(5), 103-120.

Nunez. N., Dahl. M.J., Tang. C.M. \& Jensen. B.L. (2007). Trial venue decisions in juvenile cases:
Mitigating and extralegal factors matter // Legal and Criminological Psychology. 12(1), p. 2139.

Peterson-Badali M. \& Warling D. (2003). The verdict on jury trials for juveniles: The effects of defendant's age on trial outcomes. Behavioral Sciences and the Law. 21(1), 63-82.

Rastogi, P., Yadav, M. (2013). Age of criminal responsibility of juvenile in India vis-a-vis global scenario: A critical review. Journal of Indian Academy of Forensic Medicine. 35(3). p. 262-271.

Resolution of the Plenum of the Supreme Court of the Russian Federation of 14.02.2000 No. 7 (an edition of 06.02.2007) "About jurisprudence on cases of crimes of minors". The Bulletin of the Supreme Court of the Russian Federation. 2000. - No. 4 (became invalid).

Statistical Prosecutor's offices of RT. (2015) The analysis of a condition of crime in the Republic of Tatarstan in 12 months 2015.

The resolution of the Plenum of the Supreme Court of the Russian Federation of 01.02.2011 No. 1 (an edition of 29.11.2016) "About jurisprudence of application of the legislation regulating features of criminal liability and punishment of minors" // the Bulletin of the Supreme Court of the Russian Federation. 2011. - No. 4.

Thi Thanh Nga Pham. (2015). Juvenile offenders in Vietnam and the right to defence. Youth Justice, 16(1), 49 - 70.

Tyagi, M. (2016). Understanding juvenile crime: Notes from the field. Economic and Political Weekly. 51(2), 23-25. 